\title{
Growth and grazing responses of two chloroplast-retaining dinoflagellates: effect of irradiance and prey species
}

\author{
Hans Henrik Jakobsen ${ }^{1,2, *}$, Per Juel Hansen ${ }^{2}$, Jacob Larsen ${ }^{3}$ \\ ${ }^{1}$ Danish Institute for Fisheries Research, Department of Marine and Coastal Ecology, Kavalergården 6, \\ 2920 Charlottenlund, Denmark \\ ${ }^{2}$ Marine Biological Laboratory, Strandpromenaden 5, 3000 Helsingør, Denmark \\ ${ }^{3}$ IOC Science and Communication Centre on Harmful Algae, Botanical Institute, Department of Phycology and Mycology, \\ Øster Farimagsgade 2D, 1353 Copenhagen K, Denmark
}

\begin{abstract}
The effect of irradiance on growth and grazing responses of 2 phagotrophic dinoflagellates, Gymnodinium gracilentum Campbell 1973 and Amphidinium poecilochroum Larsen 1985, was studied. While G. gracilentum belongs to the plankton, A. poecilochroum is a benthic species that primarily feeds on prey associated with surfaces. Both organisms are able to retain functional chloroplasts from their prey. They are both able to grow heterotrophically in the dark, but growth rates increase in the light. The maximum growth and ingestion rates of G. gracilentum are much higher than those of $A$. poecilochroum. However, the growth rate of $A$. poecilochroum is saturated at a lower irradiance $\left(\sim 6 \mu \mathrm{mol}\right.$ photons $\left.\mathrm{m}^{-2} \mathrm{~s}^{-1}\right)$ than to G. gracilentum $\left(\sim 60\right.$ to $80 \mu \mathrm{mol}$ photons $\left.\mathrm{m}^{-2} \mathrm{~s}^{-1}\right)$. Also, the irradiance required for saturation of growth for both dinoflagellates matched that found for the prey algae. The effect of light on ingestion and growth was also studied during the light and dark periods of the day. Ingestion rates of G. gracilentum were higher during the light period, while division rates were higher during the dark period. Offered a variety of prey items belonging to different algal classes, G. gracilentum selectively feeds on species belonging to the class Cryptophyceae.
\end{abstract}

KEY WORDS: Gymnodinium gracilentum $\cdot$ Amphidinium poecilochroum $\cdot$ Dinoflagellates $\cdot$ Mixotrophy $\cdot$ Feeding rates $\cdot$ Growth rates $\cdot$ Chloroplast

\section{INTRODUCTION}

Many planktonic heliozoans, foraminifers, ciliates and dinoflagellates are pure heterotrophs. However, some species within these groups have the ability to retain functional chloroplasts from ingested algal prey and thereby become mixotrophs. The most restricted form of this mixotrophy has been described in some heliozoans (Patterson \& Dürrenschmidt 1987). In these heliozoa, the mixotrophy is transitory and the retention of plastids non-obligatory. More developed relationships can be found among the ciliates. Here the plastids are placed at the periphery of the cell, probably for

*E-mail: hhj@dfu.min.dk effectiveness in light-harvesting, and are often quite constant in number (Laval-Peuto 1992). The plastids have only a limited lifespan within the ciliate cell, before they are either diluted out, digested or egested (Stoecker et al. 1988, Stoecker \& Silver 1990). In many cases, it is not known whether the relationship is facultative or obligatory. Obligate mixotrophy has been demonstrated in only 1 chloroplast-retaining ciliate, Laboea strobila (Stoecker et al. 1988).

The importance and role of retained chloroplasts for the metabolism of mixotrophic dinoflagellates is largely unknown. A notable exception is a recent study by Skovgaard (1998) that suggested sequestered chloroplasts help Gymnodinium gracilentum resist starvation at low prey densities by providing an alternative source of carbon. 
The aim of the present study was to examine (1) the effects of irradiance on the growth and ingestion rates of 2 chloroplast-retaining dinoflagellates, Gymnodinium gracilentum and Amphidinium poecilochroum; (2) cell division and feeding rates of G. gracilentum in light and dark periods of the day, and (3) the range of prey organisms qualitatively and quantitatively accepted by G. gracilentum.

\section{MATERIALS AND METHODS}

Isolation and maintenance of cultures. Gymnodinium gracilentum Campbell 1973 was isolated in July from surface water samples from the northern part of Øresund, Denmark. Rhodomonas salina was added as prey, and the cultures were maintained on a plankton wheel $(1 \mathrm{rpm})$ at an irradiance of $50 \mu \mathrm{mol}$ photons $\mathrm{m}^{-2}$ $\mathrm{s}^{-1}$ in a light:dark cycle of $16: 8 \mathrm{~h}$ at $15^{\circ} \mathrm{C}$.

Larsen (1985) originally described the benthic species Amphidinium poecilochroum as phototrophic. Later he found that A. poecilochroum was able to retain functional chloroplasts from ingested cryptophytes (Larsen 1988). The present culture of $A$. poecilochroum is the same strain as that originally isolated by Larsen $(1985,1988)$. Stock cultures were maintained by adding a few cells of $A$. poecilochroum to a culture of a small green cryptophyte Chroomonas sp., at intervals of 1 to 2 mo. The cultures were maintained in tissue bottles (Nunclon') placed on a transparent glass plate lit from below. The prey organism, Chroomonas sp., showed the same ability of adhering to surfaces as $A$. poecilochroum, suggesting that this species also lives in association with the sediment.

Experimental conditions. All experiments were conducted in autoclaved seawater based on B1 media (Hansen 1989), with a salinity of 30 psu and a temperature of $15 \pm 0.5^{\circ} \mathrm{C}$. All cells used in experiments were from cultures grown under a light:dark cycle of 16:8 h supplied from cool-light fluorescent tubes. Irradiance was measured using a radiometer (LI-COR LI-1000, Li-Cor ${ }^{\circledR}$, USA), equipped with a flat sensor (L-192SA) inside a polystyrene tissue bottle $\left(\right.$ Nucleon $\left.^{\circledR}\right)$ for Gymnodinium gracilentum and through a multidish (Nucleon ${ }^{\circledR}$ ) for Amphidinium poecilochroum in order to compensate for the absorption of light by the experimental containers. Irradiance was regulated by varying the distance between the plankton wheel and the light source in the experiments with G. gracilentum. In the case of $A$. poecilochroum, irradiance was varied by attenuation with Letratone ${ }^{\circledR}$ screening film or by varying the distance from the light source.

Growth and ingestion rates as a function of irradiance. Growth and ingestion rates for the 2 dinoflagellates were measured at different light intensities, rang- ing from 0 to $270 \mu \mathrm{mol}$ photons $\mathrm{m}^{-2} \mathrm{~s}^{-1}$ for Gymnodinium gracilentum fed Rhodomonas salina and from 0 to $80 \mu \mathrm{mol}$ photons $\mathrm{m}^{-2} \mathrm{~s}^{-1}$ for Amphidinium poecilochroum fed Chroomonas sp. Control experiments on growth rates for $R$. salina and Chroomonas sp. in monoculture were carried out parallel to experiments with the dinoflagellates. Growth rates of prey algae in monoculture were iteratively fitted to a 2nd-order equation using Sigmaplot ${ }^{\circledR}$ (Jandel Scientific, California, USA):

$$
\mu=\frac{P_{\max }\left(I-I_{\min }\right)}{I_{\max / 2}+\left(I-I_{\min }\right)}
$$

where $P_{\max }=$ maximum theoretically obtainable growth rate, $I=$ actual irradiance, $I_{\max / 2}=$ irradiance that sustains $0.5 P_{\max }$, and $I_{\min }=$ point of light compensation where growth is zero $(\mu=0)$

Growth and ingestion rates were measured for Gymodinium gracilentum and for Amphidinium poecilochroum at saturating prey concentrations of $>170 \mu \mathrm{g}^{-1}$ $\mathrm{C}^{-1}$, estimated from cell concentration and cell volume using the carbon to volume relationship given in Strathmann (1967). Prior to the experiments, all organisms were pre-incubated at experimental conditions for at least $48 \mathrm{~h}$.

Experiments with Gymnodinium gracilentum were carried out in triplicate batch cultures using $50 \mathrm{ml}$ tissue bottles and paralleled by triplicate controls for prey growth. Sampling was done between 09:00 and 12:00 h at intervals of $24 \mathrm{~h}$ in order to eliminate interference from diurnal rhythms. Cells were fixed in Lugol's solution ( $1 \%$ final concentration) and counted in a Sedgwick-Rafter chambers using an inverted microscope.

Because of the adhesive properties of Amphidinium poecilochroum and Chroomonas sp., it was not possible to obtain homogeneous samples from tissue-culture bottles. Instead, experiments with A. poecilochroum and Chroomonas sp. together and Chroomonas sp. alone were carried out in $0.4 \mathrm{ml}$ microwells (Nunclon ${ }^{\circledR}$ ). The wells were illuminated from below using unidirectional light; all cells settled to the bottom of the micro-wells without adhering to the walls, and could thus be counted with an inverted microscope. At each irradiance, 8 wells containing a suspension of $A$. poecilochroum and Chroomonas sp. and 8 wells with only Chroomonas sp. cells as controls were set up. After pre-incubation, 4 wells with $A$. poecilochroum and 4 control wells were fixed in Lugols' solution and counted. Depending on the number of $A$. poecilochroum at the beginning of the experiment, the remaining 4 experimental and 4 controls wells were fixed and counted after 3 to $5 \mathrm{~d}$.

Growth rates of Amphidinium poecilochroum and Gymnodinium gracilentum were assumed to be exponential and were estimated by linear regression of log-transformed data. Experiments with a correlation coefficient $\left(\mathrm{r}^{2}\right)$ below 0.90 were not used. 
Ingestion rates $(U)$ of both Gymnodinium gracilentum and Amphidinium poecilochroum were estimated from changes in prey cell numbers in treatments compared to prey densities in controls. These calculations were based on a model developed by T. Fenchel and used in previous studies (e.g. Jakobsen \& Hansen 1997 and Skovgaard 1998):

$$
\begin{gathered}
\frac{\mathrm{d} x}{\mathrm{~d} t}=\mu_{X} x-U y \\
\frac{\mathrm{d} y}{\mathrm{~d} t}=\mu_{y} y
\end{gathered}
$$

This iterative model assumes that the concentration of predator $(y)$ and prey $(x)$ increase exponentially at constant rates $\mu_{\mathrm{y}}$ and $\mu_{\mathrm{x}}$ respectively. The prey mortality induced by predators is $U y$ (where $U$ is per capita prey uptake per unit time), and was calculated iteratively on a computer with steps of $0.01 \mathrm{~h}$. However, because of the use of wells in experiments with Amphidinium poecilochroum, the ingestion rates of this species were calculated based on average values for all 4 wells.

Cell volume and number of retained chloroplasts. Cell volumes $(V)$ of all used organisms were estimated from linear dimensions of width $(w)$ and length (l) assuming a longitudinal prolate with a spherical crosssection:

$$
V=\frac{\pi}{6} l w^{2}
$$

The cell volume was determined for Gymnodinium gracilentum grown at 4 different light intensities $(6,25$, 50 and $80 \mu \mathrm{mol}$ photons $\mathrm{m}^{-2} \mathrm{~s}^{-1}$ ) and pre-incubated at excess food concentration for at least $72 \mathrm{~h}$. The cell volume of Amphidinium poecilochroum was measured at one single irradiance (25 $\mu \mathrm{mol}$ photons $\left.\mathrm{m}^{-2} \mathrm{~s}^{-1}\right)$. Unpublished TEM photographs of G. gracilentum grown in excess of food and satiated levels of irradiance reveal that food vacuoles are spherical and larger than retained chloroplasts, and that their numbers are fairly constant $(<2)$. Retained chloroplasts are more or less fused, smaller, elongated bodies with orderly stacked cryptophyte thylakoids. In the epi-fluorescent microscope, the retained chloroplasts can be recognised and distinguished from food vacuoles through their shape and smaller size. All large spherical bodies within the cell were assumed to be food vacuoles according to their size, shape and lower fluorescence level, and they were not included in the counts. In the present study, we quantified the average total number of chloroplasts retained in G. gracilentum grown at light intensities from 7 to $75 \mu \mathrm{mol}$ photons $\mathrm{m}^{-2} \mathrm{~s}^{-1}$. Prior to counting retained chloroplasts, cells were incubated at ambient light intensities for at least 4 generations with food concentrations of $>170 \mu^{-1} \mathrm{C} \mathrm{I}^{-1}$. The counts were done at a magnification of $1000 \times$.

Growth and grazing during light and dark periods of day. These experiments were carried out at an irradiance of $60 \mu \mathrm{mol}$ photons $\mathrm{m}^{-2} \mathrm{~s}^{-1}$ in a light:dark cycle of 16:8 h. Experiments were run as triplicates, according to the protocol described above. However, sampling was done at the beginning of the light and at the beginning of the dark period.

Prey species selection in Gymnodinium gracilentum. A number of algae representing different classes were offered to Gymnodinium gracilentum as prey (Table 1). The size of these algae ranged from 3 to $11 \mathrm{~mm}$ ESD (equivalent spherical diameter). Prey cultures were maintained in $250 \mathrm{ml}$ tissue-bottles at an irradiance of 20 to $50 \mu \mathrm{mol}$ photons $\mathrm{m}^{-2} \mathrm{~s}^{-1}$. Otherwise the experimental conditions were as above.

Table 1. Gymnodinium gracilentum growth and ingestion rates of dinoflagellate fed algae belonging to different classes at an

\begin{tabular}{|c|c|c|c|c|}
\hline \multirow[t]{2}{*}{ Prey species (taxa) } & \multicolumn{2}{|c|}{ Prey } & \multicolumn{2}{|c|}{ Dinoflagellate } \\
\hline & $\begin{array}{c}\text { Growth rate } \\
\left(\mu \mathrm{d}^{-1}\right)\end{array}$ & $\begin{array}{c}\text { Size } \\
(\mathrm{ESD}, \mu \mathrm{m})\end{array}$ & $\begin{array}{c}\text { Growth rate } \\
\left(\mu \mathrm{d}^{-1}\right)\end{array}$ & $\begin{array}{l}\text { Ingestion rate } \\
\left(\text { prey cells d } \mathrm{d}^{-1}\right)\end{array}$ \\
\hline Phaeodactylum tricornutum (Bacillariophyceae) & nd & nd & No growth & nd \\
\hline Prymnesium patelliferum (Prymnesiophyceae) & nd & nd & No growth & nd \\
\hline Tetraselmis suecida (Prasinophyceae) & nd & nd & No growth & nd \\
\hline Isochrysis galbana (Prymnesiophyceae) & nd & nd & No growth & nd \\
\hline Chroomonas vectensis (Cryptophyceae) & nd & nd & No growth & nd \\
\hline Chroomonas sp. (Cryptophyceae) & $0.19(0.14)$ & 6 & $0.07(0.05)$ & $1.70(0.19)$ \\
\hline Rhodomonas marina (Cryptophyceae) & $1.1(0.07)$ & 10.3 & $0.29(0.07)$ & $0.65(0.05)$ \\
\hline Plagioselmis prolonga (Cryptophyceae) & $0.24(0.02)$ & 6.6 & $1.25(0.1)$ & $1.8(0.05)$ \\
\hline Teleaulax amphioxeia (Cryptophyceae) & $0.31(0.07)$ & 8.5 & $1.51(0.07)$ & $1.58(0.02)$ \\
\hline Rhodomonas salina (Cryptophyceae) & $0.84(0.072)$ & 7.8 & $0.55(0.07)$ & $1.75(0.05)$ \\
\hline
\end{tabular}
irradiance of $60 \mu \mathrm{mol}$ photons $\mathrm{m}^{-2} \mathrm{~s}^{-1}$. No growth indicates that G. gracilentum was unable to grow on prey. Values are means (SE); ESD: equivalent spherical diameter; nd: no data 


\section{RESULTS}

\section{Effects of irradiance on bioenergetics of Gymnodinium gracilentum and Amphidinium poecilochroum}

Gymnodinium gracilentum was able to grow at a rate of $0.53 \mathrm{~d}^{-1}$ in the dark when supplied with food in excess. The growth rate remained at this level up to an irradiance of $\sim 25 \mu \mathrm{mol}$ photons $\mathrm{m}^{-2} \mathrm{~s}^{-1}$. Above an irradiance of $25 \mu \mathrm{mol}$ photons $\mathrm{m}^{-2} \mathrm{~s}^{-1}$, the growth rate increased to a maximum level of $1.2 \mathrm{~d}^{-1}$ at an irradiance of 60 to $80 \mu \mathrm{mol}$ photons $\mathrm{m}^{-2} \mathrm{~s}^{-1}$ (Fig. 1a). Ingestion rates of $G$. gracilentum fed Rhodomonas salina

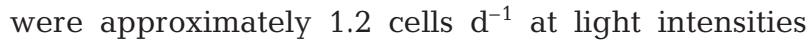
$<25 \mu \mathrm{mol}$ photons $\mathrm{m}^{-2} \mathrm{~s}^{-1}$ (Fig. 2a). Ingestion rates increased with increasing irradiance to a maximum level of $\sim 2.4$ to 3.4 cells d $^{-1}$ at light intensities $>80 \mu \mathrm{mol}$ photons $\mathrm{m}^{-2} \mathrm{~s}^{-1}$.
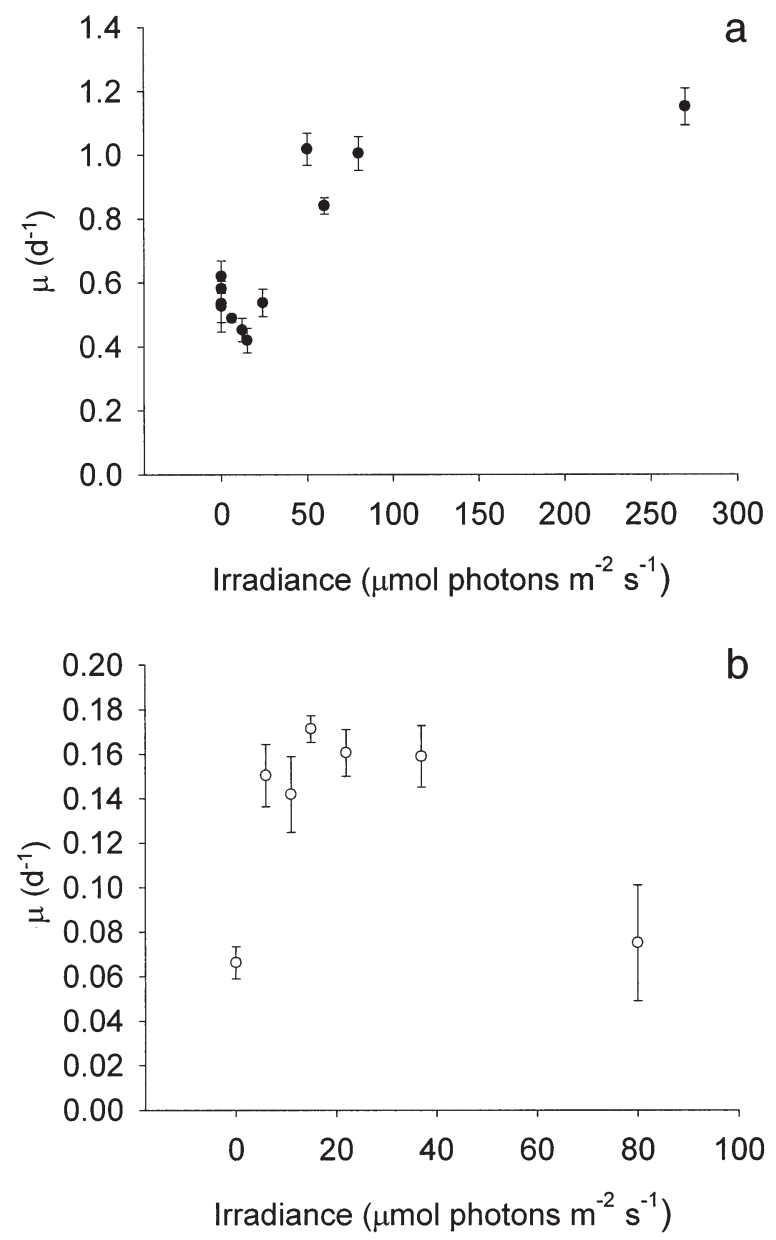

Fig. 1. (a) Gymnodinium gracilentum, and (b) Amphidinium poecilochroum growth rates as a function of irradiance. Data points are treatment means $\pm \mathrm{SE}$
Amphidinium poecilochroum grew at a rate of $0.06 \mathrm{~d}^{-1}$ in the dark when supplied with food in excess. The growth rate of $A$. poecilochroum increased to a maximum of $0.17 \mathrm{~d}^{-1}$ when exposed to light intensities $>6 \mu$ mol photons $\mathrm{m}^{-2} \mathrm{~s}^{-1}$ (Fig. 1b). Growth rate decreased at irradiancies $>40 \mu \mathrm{mol}$ photons $\mathrm{m}^{-2} \mathrm{~s}^{-1}$. Ingestion rates of $A$. poecilochroum when fed on

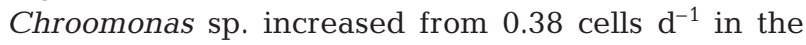
dark to approximately 0.53 cells d $^{-1}$ at light intensities above $6 \mu \mathrm{mol}$ photons $\mathrm{m}^{-2} \mathrm{~s}^{-1}$ (Fig. 2b). At light intensities $>40 \mu \mathrm{mol}$ photons $\mathrm{m}^{-2} \mathrm{~s}^{-1}$, ingestion rate decreased to 0.34 Chroomonas sp. cells $\mathrm{d}^{-1}$ at $80 \mu \mathrm{mol}$ photons $\mathrm{m}^{-2} \mathrm{~s}^{-1}$ (Fig. 2b).

\section{Cell volume and number of vacuoles}

The cell volume of Gymnodinium gracilentum remained constant at $\sim 500 \mu^{3}$ at all light intensities
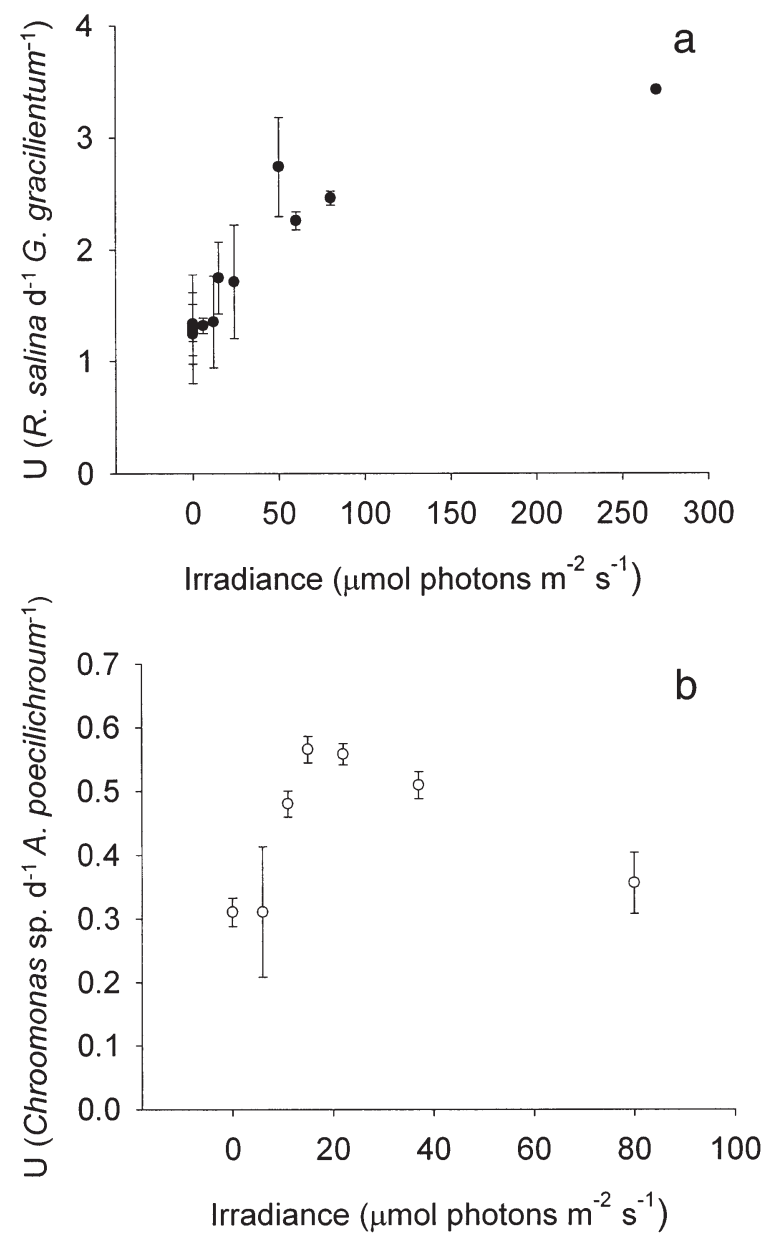

Fig. 2. (a) Gymnodinium gracilentum, and (b) Amphidinium poecilochroum ingestion rates, $U$, as a function of irradiance. Data points are treatment means $\pm \mathrm{SE}$ 


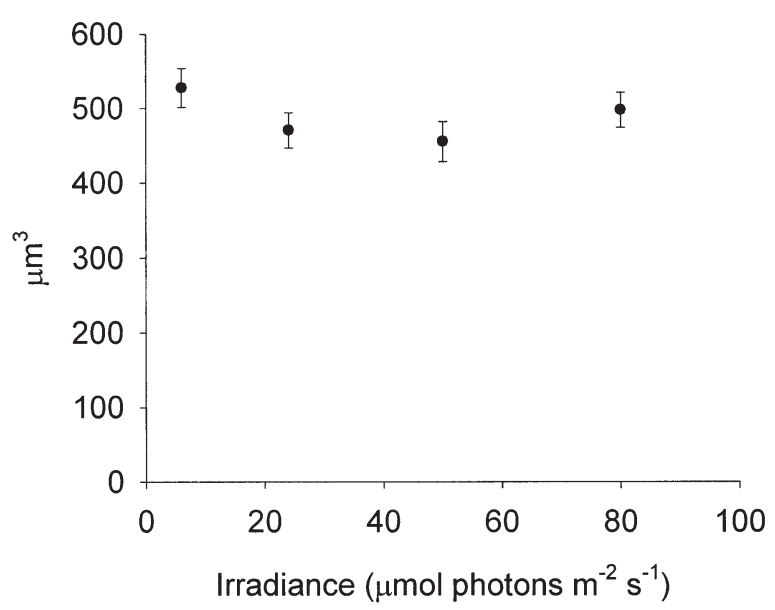

Fig. 3. Gymnodinium gracilentum cell volume as a function of irradiance. Data points are treatment means $\pm \mathrm{SE}$

(Fig. 3). The cell volume of $A$, poecilochroum was $1100 \mu^{3}$ at an irradiance of $25 \mu \mathrm{mol}$ photons $\mathrm{m}^{-2} \mathrm{~s}^{-1}$. The number of retained chloroplasts (vacuoles) in G. gracilentum cells appeared to be unaffected by irradiance, and constant at about 6 chloroplasts per individual (Fig. 4).

\section{Growth rate of prey algae in monoculture}

Growth rates of prey algae were studied as a function of irradiance. Data were fit to Eq. (1) using a sigma plot (Jandel Scientific, California, USA) and the results are shown in Table 2 . The maximum growth rate of Rhodomonas salina was 6 times higher than that of Chroomonas sp. However, the light compensation point of Chroomonas sp. was $0.13 \mu \mathrm{mol}$ photons $\mathrm{m}^{-2} \mathrm{~s}^{-1}$, while it was $7.8 \mu \mathrm{mol}$ photons $\mathrm{m}^{-2} \mathrm{~s}^{-1}$ for $R$. salina. The light intensity sustaining $0.5 \mu_{\max }$ was $2.9 \mu \mathrm{mol}$ photons $\mathrm{m}^{-2} \mathrm{~s}^{-1}$ for Chroomonas sp., that for $R$. salina was $35 \mu \mathrm{mol}$ photons $\mathrm{m}^{-2} \mathrm{~s}^{-1}$ (Table 2). The growth of Chroomonas sp.; declined at a light intensity $>37 \mu \mathrm{mol}$ photons $\mathrm{m}^{-2}$ $\mathrm{s}^{-1}$. Growth for $R$. salina was not affected at an irradiance as high as $270 \mu \mathrm{mol}$ photons $\mathrm{m}^{-2} \mathrm{~s}^{-1}$ (Fig. 5).

\section{Growth and grazing during dark and light periods of day}

The growth rate of Gymnodinium gracilentum (Student's $t$-test: $\mathrm{p}=$ $0.0002 ; \alpha=0.05)$ and Rhodomonas salina ( $t$-test: $\mathrm{p}=0.0001 ; \alpha=0.05$ ) was

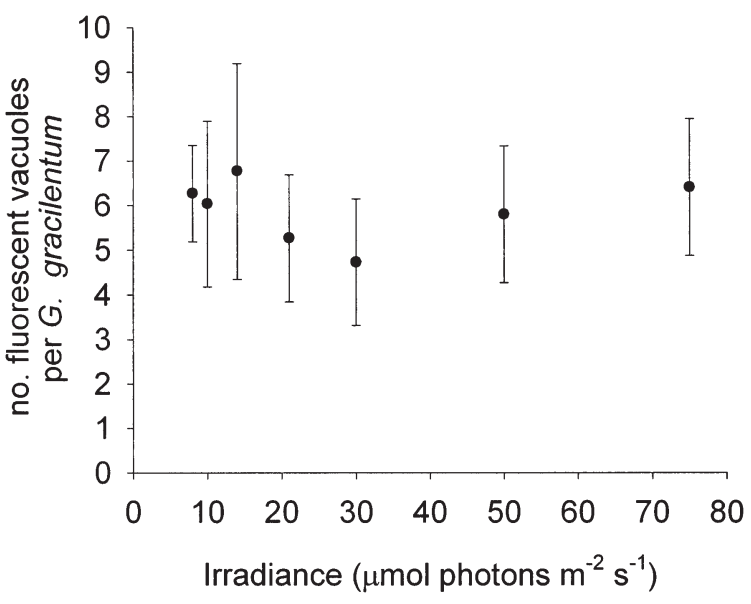

Fig. 4. Gymnodinium gracilentum. Number of food vacuoles as a function of irradiance. Data points are treatment means $\pm \mathrm{SE}$

significantly higher in the dark than in the light (Fig. 6). In contrast to the growth of G. gracilentum, its ingestion of $R$. salina was significantly higher in the light than in the dark ( $t$-test: $\mathrm{p}=0.0001 ; \alpha=0.05$, Fig. 6).

\section{Prey species selection in Gymnodinium gracilentum}

In experiments where Gymnodinium gracilentum was offered algae within the size range 3 to $10.3 \mu \mathrm{m}$ from different algal classes, food uptake and growth was only observed with cryptophyte prey (Table 1). Ingestion rates, in terms of biovolume, showed little variation between the different cryptophyte species $\left(U=356 \pm 126 \mu^{3} \mathrm{~d}^{-1}\right.$, mean $\left.\pm \mathrm{SD}\right)$. Despite this, the growth rate of $G$. gracilentum varied considerably $\left(\mu\left[\mathrm{d}^{-1}\right]=0.46 \pm 0.43\right.$, mean $\left.\pm \mathrm{SD}\right)$. No relationship was found between growth of the prey algae and growth of the dinoflagellate.
Table 2. Fitted parameter of growth, $P\left(\mu \mathrm{d}^{-1}\right)$, as a function of irradiance ( $\mu \mathrm{mol}$ photons $\mathrm{m}^{-2} \mathrm{~s}^{-1}$ ) of prey organisms used. $P_{\max }$ : maximum obtainable growth rate; $I_{\min }$ : minimum irradiance that sustains minimum growth; $I_{\max / 2}$ : irradiance that sustains $50 \%$ of $P_{\max }$. Values in table were used to draw regression lines in

Fig. 5. Values in parentheses $=\mathrm{SE}$ of mean

\begin{tabular}{|llcc|}
\hline & $\begin{array}{c}P_{\max } \\
(\mathrm{d}-1)\end{array}$ & $\begin{array}{c}I_{\min } \\
(\mu \mathrm{mol} \text { photons } \\
\left.\mathrm{m}^{-2} \mathrm{~s}^{-1}\right)\end{array}$ & $\begin{array}{c}I_{\max / 2} \\
(\mu \mathrm{mol} \text { photons } \\
\left.\mathrm{m}^{-2} \mathrm{~s}^{-1}\right)\end{array}$ \\
\hline Rhodomonas salina & $1.29(0.1)$ & $7.75(1.22)$ & $35(8.2)$ \\
Chroomonas sp. & $0.23(0.02)$ & $0.13(0.17)$ & $2.89(1.8)$ \\
\hline
\end{tabular}



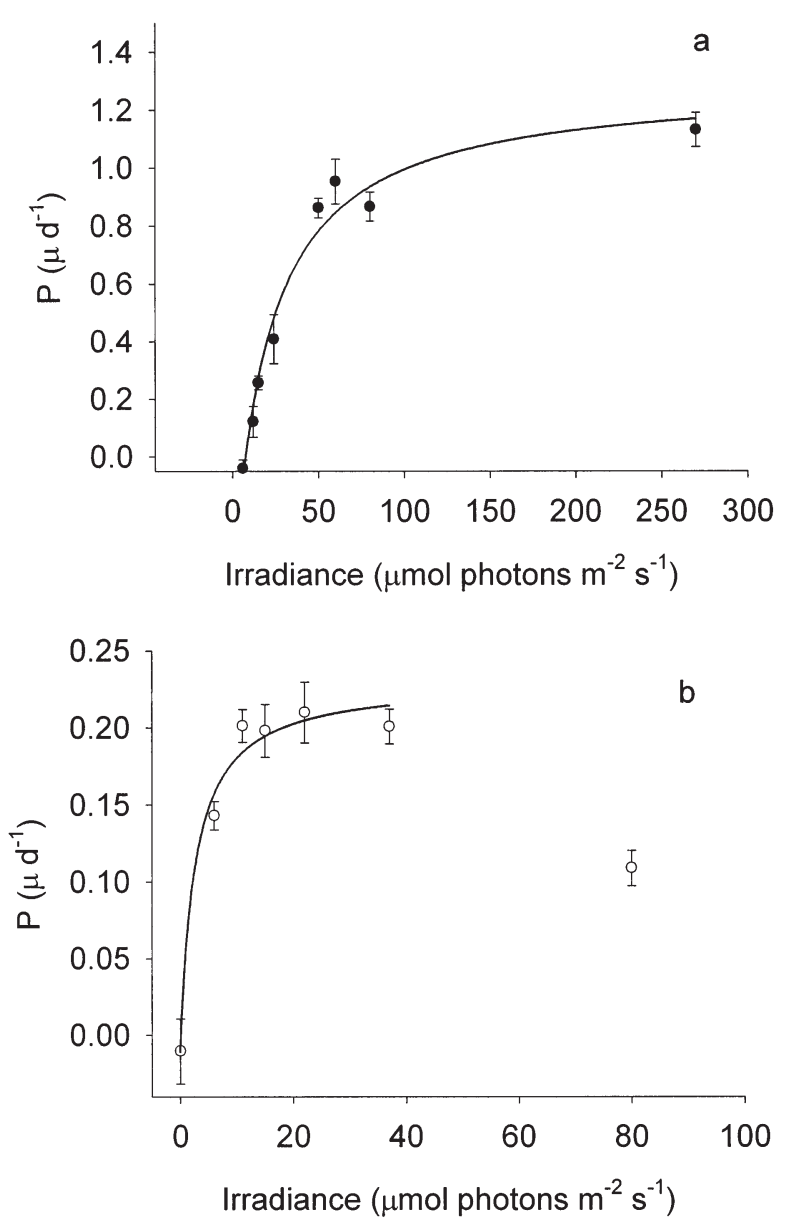

Fig. 5. (a) Rhodomonas salina, and (b) Chroomonas sp. growth rates, $P\left(\mu \mathrm{d}^{-1}\right)$, as a function of irradiance. Data points are treatment means $\pm \mathrm{SE}$

\section{DISCUSSION}

\section{Growth and feeding rates as a function of irradiance}

The 2 dinoflagellates studied here were able to grow in the dark when supplied with food. However, growth rates of both species were positively affected by light. Thus, both may be considered as facultative mixotrophs. Maximum growth of Gymnodinium gracilentum in the light was close to that expected from rate calculated from body size/max. growth rate relationships reported in the literature (Banse 1982, Hansen 1992, Sherr \& Sherr 1994, Hansen et al. 1997). The maximum growth rate of the benthic dinoflagellate Amphidinium poecilochroum was however approximately 4 to 5 times slower than that of G. gracilentum. Its light-dependent growth saturated at lower irradiance, and became light-inhibited at irradiances exceeding $40 \mu \mathrm{mol}$ photons $\mathrm{m}^{-2} \mathrm{~s}^{-1}$. A. poecilochroum
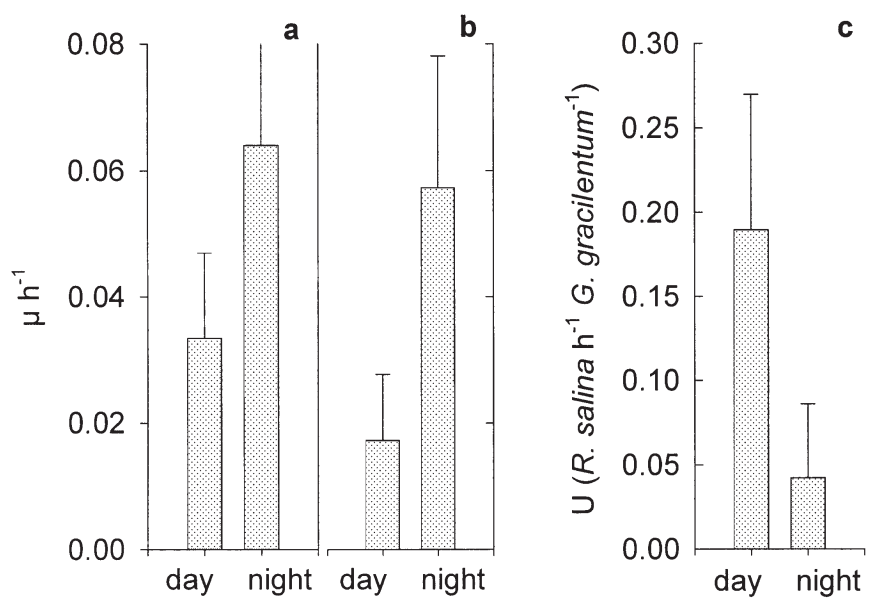

Fig. 6. Growth $\left(\mu \mathrm{h}^{-1}\right)$ of (a) Gymnodinium gracilentum and (b) Rhodomonas salina, and (c) ingestion rates, $U$ (prey cells $\mathrm{h}^{-1}$ ), of G. gracilentum during day and night. Error bars $=\mathrm{SD}$

and its prey Chroomonas sp. live interstitially in the sediments, where light is limited, while G. gracilentum lives in the plankton. It therefore seems that both $A$. poecilochroum and Chroomonas sp. are adapted to a low-light environment.

A positive relationship was found between ingestion rate and irradiance for both of the studied dinoflagellates. Thus, the overall growth yield (= ingestion rate/ growth rate), in terms of volume, was largely unaffected by irradiance. At least 2 possibilities exist which might explain this observation. One possibility is that light acts directly by increasing the degradation rate of the food as suggested by Skovgaard (1998). Our data cannot support this hypothesis. While the maximum growth and ingestion rates of Gymnodinium gracilentum were achieved at an irradiance $>80 \mu \mathrm{mol}$ photons $\mathrm{m}^{-2} \mathrm{~s}^{-1}$, the maximum growth and ingestion rates of Amphidinium poecilochroum were reached at an irradiance of $10 \mu \mathrm{mol}$ photons $\mathrm{m}^{-2} \mathrm{~s}^{-1}$.

Another possibility is that photosynthesis by the retained chloroplasts supplies the dinoflagellate with an additional carbon source which is rapidly incorporated into biomass, leading to an enhanced growth rate. Because the overall growth yield of both Gymnodinium gracilentum and Amphidinium poecilochroum does not differ as a function of irradiance, a larger fraction of the prey carbon must therefore be egested. This hypothesis is supported by the light:dark experiment. In this experiment, ingestion rates were substantially higher during the light period compared to ingestion rates in the dark period of the day. Thus, these dinoflagellates seem to act as mixotrophs during the light period and as a heterotrophs during the dark period.

We have shown that the number of fluorescent vacuoles retained is independent of irradiance (Fig. 4) and 
that the growth response of the 2 dinoflagellates matches the growth response of the prey algae (cf. Figs. 1 \& 5). This fact suggests that prey cells and retained chloroplasts must be turned over faster at higher irradiances. The retained chloroplast may therefore be an analogue to a chargeable unit, e.g. a battery, which is able to fix a finite amount of carbon. As light increases, the amount of carbon fixed per unit sequestered chloroplast increases, but the time the chloroplast is retained by the dinoflagellate decreases.

Little is known about the length of time chloroplasts can be retained and still be photosynthetically active in dinoflagellates. In the case of Gymnodinium gracilentum, it has previously been shown that the chloroplasts are photosynthetically active for about $48 \mathrm{~h}$ (Skovgaard 1998). In Pfiesteria piscicida, Lewitus et al. (1999) found retained chloroplasts in part of the population for at least $13 \mathrm{~d}$. However, whether the retained chloroplasts were photosynthetically active is not clear from their study.

\section{Prey specificity of chloroplast-retaining dinoflagellates}

The chloroplast retaining Gymnodinium gracilentum selectively fed on cryptophytes. Chloroplast retention is found in several species of dinoflagellates (Table 3). In all known cases, chloroplasts retained by dinoflagellates are derived from cryptophytes. Some species such as G. gracilentum, and possibly also Amphidinium poecilochroum and A. latum, are selective feeders on cryptophytes (Larsen 1988, Horiguchi \& Pienaar 1992), indicating that they are able to recognize and distinguish between their prey. Pfiesteria piscicida differs slightly and can feed on a variety of prey organisms (Glasgow et al. 1998). Nevertheless, P. piscicida only retains and hosts chloroplasts from cryptophytes (Lewitus et al. 1999).

Other groups of protists are known to host chloroplasts obtained from their prey. Foraminifers, ciliates and heliozoans have all been shown to retain chloroplasts from a variety of algal classes, including dia- toms, dinoflagellates or cryptophytes. Some difference does exist though. In ciliates and heliozoans, some species may retain chloroplasts from different algal classes, while in foraminifers species are known to retain 1 type of chloroplast. (Leutenegger 1984, LavalPeuto \& Febvre 1986, Patterson \& Dürrenschmidt 1987 , Stoecker \& Silver 1990).

It was interesting to observe that Gymnodinium gracilentum in our experiments ingested all tested cryptophytes at an almost similar rate (in terms of biovolume), but that the growth response differed considerably. The main reason for this may be a combination of the ability of the dinoflagellate to utilise the chloroplasts of the prey, and the rate and degree by which the prey can be digested.

\section{Ecological implications}

Our knowledge of the quantitative importance of dinoflagellates that retain chloroplasts in natural habitats is generally sparse, and biased by insufficient knowledge on the autecology of dinoflagellates. The main reason is that it is impossible to routinely distinguish these dinoflagellates from ordinary phototrophic dinoflagellates with the current techniques for quantification. In fact, Amphidinium poecilochroum was first described as a phototrophic dinoflagellate (Larsen 1985).

Nevertheless, some basic principles can be extracted from data on the few species studied in the laboratory so far. The studies of Skovgaard (1998) and Lewitus et al. (1999) and the present observations suggest that chloroplast-sequestering dinoflagellates grow well in the light, but only when food is available.

If sufficient food is available dinoflagellates such as the species studied will increase in number faster than obligate phototrophs when light is limited. In an environment with fluctuating food availability, a chloroplast-retaining dinoflagellate such as Gymnodinium gracilentum will survive better than pure heterotrophic dinoflagellates because of its ability to prolong growth and survival (Skovgaard 1998). Thus, this

Table 3. Prey items of chloroplast-retaining dinoflagellates. Data from the literature

\begin{tabular}{|lll|}
\hline Predator & Prey species (class) & Source \\
\hline Amphidinium latum & (Cryptophyceae) & Horiguchi \& Pienaar (1992) \\
Amphidinium poecilochroum & Chroomonas sp. (Cryptophyceae) & Larsen (1988) \\
Amphidinium acidotum & (Cryptophyceae) & Wilcox \& Wedmayer (1984), Fields \& Rhodes (1991) \\
Gymnodinium aeruginosum & (Cryptophyceae) & Schnepf et al. (1989) \\
Gymnodinium gracilentum & (Cryptophyceae) see Table 1 & This study \\
Pfiesteria piscicida & Rhodomonas sp. (Cryptophyceae) & Lewitus et al. (1999) \\
a'Suspected to retain chloroplasts from prey & \\
\hline
\end{tabular}


organism will have the potential to find a niche in a fluctuating environment where light or prey resources are sometimes limited. Amphidinium poecilochroum behaves in fairly much the same way as G. gracilentum. It does not grow very fast, but the turnover rate of the retained chloroplasts is accordingly lower, suggesting that this dinoflagellate is even more fit to manage fluctuating environments. However, with such a low growth rate, it will probably only thrive in habitats in which grazing is low.

Acknowledgements. This work was supported by a PhD grant to H.H.J. from the Danish Research Academy, and a grant to P.J.H. by the Danish Science Research Council (contract no. 9801391). Special thanks to Thomas Kiørboe for valuable comments on an earlier draft of this manuscript.

\section{LITERATURE CITED}

Banse K (1982) Cell volumes, maximal growth rate of unicellular algae and ciliates and the role of ciliates in the marine pelagial. Limnol Oceanogr 27:1059-1071

Fields SD, Rhodes RG (1991) Ingestion and retention of Chroomonas spp. (Cryptophyceae) by Gymnodinium acidotum (Dinophyceae). J Phycol 27:525-529

Glasgow HG, Lewitus AJ, Burkholder JM (1998) Feeding behavior of the ichthyotoxic estuarine flagellate, Pfiesteria piscicida, on amino acids, algal prey and fish vs mammalian erythrocytes. In: Blanco RB, Fernbndez ML, Wyatt T (eds) Harmful algae. UNESCO, Paris, p 394-397

Hansen PJ (1989) The red tide dinoflagellate Alexndrium tamarense: effect on behaviour and growth of a tintinnid ciliate. Mar Ecol Prog Ser 53:105-116

Hansen PJ (1992) Prey size selection, feeding rates and growth dynamics of heterotrophic dinoflagellates with special emphasis on Gyrodinium spirale. Mar Biol 114: 327-334

Hansen PJ, Bjørnsen PK, Hansen B (1997) Zooplankton grazing and growth: scaling within the $2-2000 \mu \mathrm{m}$ body range. Limnol Oceanogr 42:687-704

Horiguchi T, Pienaar RN (1992) Amphedinium latum Lebour (Dinophyceae), a sand-dwelling dinoflagellate feeding on Cryptomonads. Jpn J Phycol 40:353-363

Editorial responsibility: John Austin (Assistant Editor), Oldendorf/Luhe, Germany
Jakobsen HH, Hansen PJ (1997) Prey size selection, grazing and growth response of the small heterotrophic dinoflagellate Gymnodinium sp. and the ciliate Balanion comatum-a comparative study. Mar Ecol Prog Ser 158: $75-86$

Larsen J (1985) Algal studies of the Danish Wadden Sea. II. A taxomonic study of psammobious dinoflagellates. Opera Bot 79:14-37

Larsen J (1988) An ultrastructural study of Amphedinium poecilochroum (Dinophyceae), a phagotrophic dinoflagellate feeding on small species of cryptophytes. Phycologia 27:366-377

Laval-Peuto M (1992) Plastidic protozoa. In: Reisser W (ed) Algae and symbioses: plants, animals, fungi, viruses, interactions explored. Biopress, Bristol, p 471-499

Laval-Peuto M, Febvre M (1986) On plastid symbiosis in Tontonia apendiculariformis (Ciliophora, Oligotrichina). Biosystems 19:137-158

Leutenegger S (1984) Symbiosis in benthic foraminifera: specifity and host adaptation. J Foraminifer Res 14:16-35

Lewitus AJ, Glasgow HG, Burkholder JM (1999) Kleptoplastidy in the toxic dinoflagellate Pfiesteria piscicida (Dinophyceae). J Phycol 35:303-312

Patterson D, Dürrenschmidt M (1987) Selective retention of chloroplasts by algivorous heliozoa: fortuitous chloroplast symbiosis. Eur J Protistol 23:51-55

Schnepf E, Winter S, Mollenhauer D (1989) Gymnodinium aeroginosum (Dinophyta): a blue-green dinoflagellate with a vestigal, anucleate, cryptophycean endosymbiont. Plant Syst Evol 164:75-91

Sherr EB, Sherr BF (1994) Bacterivory and herbivory: key roles of phagotrophic protists in pelagic food webs. Microb Ecol 28:223-235

Skovgaard A (1998) Role of chloroplast retention in a marine dinoflagellate. Aquat Microb Ecol 15:293-301

Stoecker DK, Silver MW (1990) Replacement and aging of chloroplasts in Strombidium capitatum (Ciliophora: Oligotrichida). Mar Biol 107:491-502

Stoecker DK, Silver MW, Michaels AE, Davis LH (1988) Obligate mixotrophy in Laboea strobila, a ciliate which retains chloroplasts. Mar Biol 99:415-423

Strathmann RR (1967) Estimating the organic content of phytoplankton from cell volume or plama volume. Limnol Oceanogr 12:411-418

Wilcox LW, Wedemayer GJ (1984) Gymnodinium acidotum (Porrophyta), a dinogflagellate with an endosymbiontic cryptomonad. J Phycol 20:236-242

Submitted: November 15, 1999; Accepted: February 17, 2000 Proofs received from author(s): July 7, 2000 